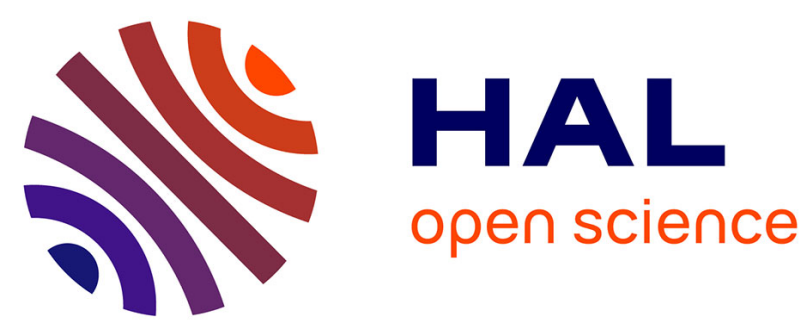

\title{
Capturing a Square Planar Gold(III) Complex Inside a Plati- num Nanocage: A Combined Experimental and Theoretical Study
}

Emmanuel Puig, Christophe Desmarets, Geoffrey Gontard, Marie Noelle Rager, Andrew L Cooksy, Hani Amouri

\section{To cite this version:}

Emmanuel Puig, Christophe Desmarets, Geoffrey Gontard, Marie Noelle Rager, Andrew L Cooksy, et al.. Capturing a Square Planar Gold(III) Complex Inside a Plati- num Nanocage: A Combined Experimental and Theoretical Study. Inorganic Chemistry, 2019, 58 (5), pp.3189-3195. 10.1021/acs.inorgchem.8b03272 . hal-02341584

\section{HAL Id: hal-02341584 https://hal.sorbonne-universite.fr/hal-02341584}

Submitted on 31 Oct 2019

HAL is a multi-disciplinary open access archive for the deposit and dissemination of scientific research documents, whether they are published or not. The documents may come from teaching and research institutions in France or abroad, or from public or private research centers.
L'archive ouverte pluridisciplinaire HAL, est destinée au dépôt et à la diffusion de documents scientifiques de niveau recherche, publiés ou non, émanant des établissements d'enseignement et de recherche français ou étrangers, des laboratoires publics ou privés. 


\title{
Capturing a Square Planar Gold(III) Complex Inside a Plati- num Nanocage: A Combined Experimental and Theoretical Study
}

Emmanuel Puig, ${ }^{a}$ Christophe Desmarets, ${ }^{* a}$ Geoffrey Gontard ${ }^{a}$, Marie Noelle Rager, ${ }^{\mathrm{b}}$ Andrew L. Cooksy, ${ }^{\mathrm{c}}$ and Hani Amouri, ${ }^{* a}$

[a] Sorbonne Université-Faculté des Sciences et Ingénerie Campus Pierre et Marie Gurie, GNRS, IPGM (UMR 8232), 4 place Jussieu, 75252 Paris cedex 05, France.

[b] Chimie ParisTech, PSL University, NMR Facility, F-75005 Paris, France.

[c] Department of Chemistry, San Diego State U., San Diego CA 921821030 , USA

\begin{abstract}
A novel synthetic procedure was set up to gain access to platinum coordination cages $\mathrm{Pt}_{2} \mathrm{~L}_{4}$, which are less investigated compared to their palladium counterparts. This $\mathrm{Pt}_{2} \mathrm{~L}_{4}$ nanocage exhibits an adequate cavity for guest encapsulation. Indeed the $\mathrm{Au}(\mathrm{III})$ metal complex $\left[\mathrm{Au}(\mathrm{bdt})_{2}\right]$ - $(\mathrm{bdt}=$ benzene-1,2dithiolate) was successfully captured inside the cavity, in contrast to the analogous palladium cage which failed to host the gold complex. This result represents a rare example where a metal complex with thioligands can be encapsulated in a coordination cage. Moreover it highlights the role of the metal center and the robustness of the platinum cage for host-guest chemistry. This discovery will inspire researchers in this area to pay more attention to Pt-cages. The host-guest system was fully characterized by NMR techniques and X-ray crystallographic analysis. Moreover the nature of the host-guest interaction in this unique example was investigated and rationalized by DFT computational studies.
\end{abstract}




\section{- INTRODUCTION}

Host-guest chemistry of self-assembled coordination cages has attracted much attention in the last two decades. ${ }^{1-6}$ These cages can now be obtained with different shapes and display cavities with controllable sizes. ${ }^{7-15}$ As a consequence, a wide range of applications have been investigated including molecular sensing, chiral separation, drug delivery and catalytic properties. ${ }^{16-20}$ Among these cages, particular interest has been devoted to the formation of the $\mathrm{M}_{2} \mathrm{~L}_{4}$ cage-type. ${ }^{21-26}$ These architectures display high symmetry and are capable of encapsulating guests such as anions or organic molecules but to a lesser extent metal compounds. ${ }^{27-30}$ They are usually obtained by mixing metal precursors displaying four available coordination sites and bidentate ligands. While $\mathrm{Pd}_{2} \mathrm{~L}_{4}$ cages have been intensively described, surprisingly so far only a few platinum analogues have been reported. ${ }^{31,32}$

Our group have developed a variety of metallacages of type $\mathrm{M}_{2}\left(\mathrm{~L}^{1}\right)_{4}$ based on $\mathrm{Co}(\mathrm{II})$ and $\mathrm{Cu}(\mathrm{II})$ using a semi-rigid bidentate ligand where $\mathrm{L}^{1}$ $=$ 1,3-bis(benzimidazol-1-ylmethyl)-2,5-dimethoxy4,6-dimethylbenzene. ${ }^{33-36}$ We also demonstrated that these systems are capable of selectively encapsulating weakly coordinated anions such as $\mathrm{BF}_{4}$ and $\mathrm{PF}_{6}$ anions. ${ }^{35}$ However in the presence of strongly coordinated anions the related coordination polymers were obtained instead, highlighting the lability of metal-ligand $\left(\mathrm{L}^{1}\right)$ interaction in these metallacages. $^{34}$

Subsequently, we shifted our efforts towards the design of another kind of $\mathrm{M}_{2} \mathrm{~L}_{4}$ metallacage but using the more rigid pyridine-based ligands. ${ }^{37}$ The latter are more strongly bound to the metal centers. Indeed we demonstrated that the metallacage $\operatorname{Pd}_{2} \mathrm{~L}_{4}$ successfully accommodates anionic organometallic species $\left[\mathrm{Pt}\left(\mathrm{NO}_{2}\right)_{4}\right]^{2-}$ inside the cavity. ${ }^{29}{ }^{1} \mathrm{H}-\mathrm{NMR}$ studies and DFT calculations allowed us to rationalize the nature of non-covalent interactions occurring between the guest complex and the $\mathrm{Pd}_{2} \mathrm{~L}_{4}$ cage. It is worth mentioning that encapsulating kinetically labile metal complexes inside self-assembled cages is a difficult task and only few examples have been reported. ${ }^{18,27,38}$

\section{RESULTS AND DISCUSSION}

Pursuing our investigations in this area we sought again to accommodate metal complexes, but now displaying thio-ligands such as $[n-$ $\left.\mathrm{Bu}_{4} \mathrm{~N}\right]\left[\mathrm{Au}(\mathrm{bdt})_{2}\right]$ (bdt $=$ benzene- 1,2- dithiolate). This type of molecule is highly challenging because it contains strongly coordinating sulfur centres and displays interesting magnetic and redox properties. ${ }^{39}$, ${ }^{40}$ In this paper we report the synthesis of nanocages of the type $\mathrm{M}_{2} \mathrm{~L}_{4}(\mathrm{M}=\mathrm{Pd}, \mathrm{Pt}$ ) (Figure
1) and our investigations towards the encapsulation of a square planar $\mathrm{Au}(\mathrm{III})$ guest molecule.

Our first approach was to examine whether our $\operatorname{Pd}_{2} \mathrm{~L}_{4}$ cage available in hand, $(\mathrm{L}=1,3-$ bis(pyridin-3-ylethynyl)-5-methoxybenzene) is adequate to host the gold(III) complex since we demonstrated that such a metallacage was able to accommodate $\left[\mathrm{PtCl}_{4}\right]^{2-}$ species inside the cavity. ${ }^{37} \mathrm{We}$ reasoned that recognition could be enhanced through electrostatic interactions between the positively charged $\mathrm{Pd}(\mathrm{II})$ cations and the anionic nature of the guest but also by hydrogen bonding provided by the endohedral hydrogens of ligand L pointing towards the interior of the cavity. The host-guest studies were carried out

in $\mathrm{CD}_{3} \mathrm{CN} / \mathrm{DMSO}-d_{6}$ (4:1) mixture due to solubility limitations. Thus, when one equivalent of [n$\left.\mathrm{Bu}_{4} \mathrm{~N}\right]\left[\mathrm{Au}(\mathrm{bdt})_{2}\right]$ was added to a solution of cage $\left[\mathrm{Pd}_{2}(\mathrm{~L})_{4}\right][\mathrm{OTf}]_{4} \quad(\mathbf{1 a})$, the ${ }^{1} \mathrm{H}$ NMR spectrum showed the formation of multiple peaks relative to the starting material $\mathbf{1 a}$ and the appearance of the free ligand L and unidentified materials (Figure S1). Further addition of another equivalent of $\left[\mathrm{Au}(\mathrm{bdt})_{2}\right]^{-}$to the reaction mixture provided $\mathrm{L}$ in equal amount to the metallacage $\mathbf{1 a}$, while addition of a third equivalent led to the decomposition of the metallacage and formation of the free ligand L almost quantitatively along with free $\left[\mathrm{Au}(\mathrm{bdt})_{2}\right]^{-}$as well . We reasoned that the analogous $\mathrm{Pt}_{2} \mathrm{~L}_{4}$ cage should display stronger Pt-ligand interaction and hence should be more appropriate to study this type of host-guest interaction with the challenging $\mathrm{Au}(\mathrm{III})$ guest $\left[n-\mathrm{Bu}_{4} \mathrm{~N}\right]\left[\mathrm{Au}(\mathrm{bdt})_{2}\right]$.

Our first step was to find a rational synthetic approach to this kind of platinum nanocage $\mathrm{Pt}_{2} \mathrm{~L}_{4}$. Gratifyingly after several attempts we found that treatment of ligand $\mathrm{L}$ with freshly prepared $\left[\mathrm{Pt}(\mathrm{EtCN})_{4}\right][\mathrm{OTf}]_{2}$ precursor in acetonitrile solution at $80^{\circ} \mathrm{C}$ for several days afforded the desired nanocage complex $\left[\mathrm{Pt}_{2} \mathrm{~L}_{4}\right][\mathrm{OTf}]_{4}[\mathbf{1 b}]$ in $80 \%$ yield (figure 1).

Figure 1. Schematic representation of the ligand L and the metallacages $\left[\mathrm{M}_{2} \mathrm{~L}_{4}\right][\mathrm{OTf}]_{4} . \mathrm{M}=\mathrm{Pd}(\mathbf{1} \mathbf{a}) ; \mathrm{M}=$ $\operatorname{Pt}(\mathbf{1 b})$.
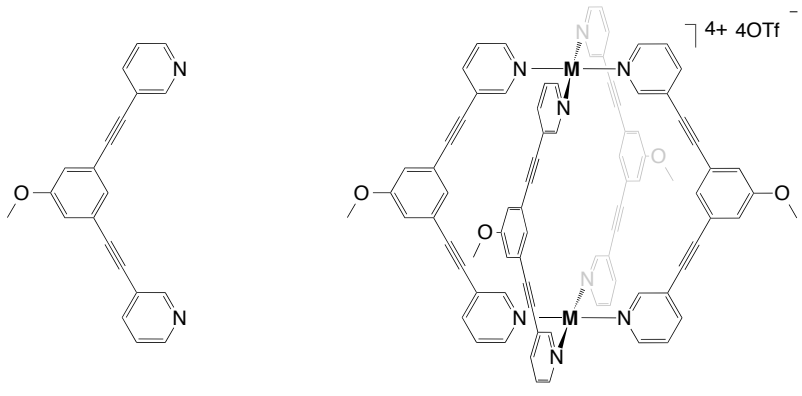

$\mathbf{L}$ 
The infrared spectrum of $1 \mathrm{~b}$ showed the presence of triflate anions bands at $1256 \mathrm{~cm}^{-1}$ and displayed the alkyne stretching band at $2219 \mathrm{~cm}^{-1}$. Moreover the integrity of the nanocage $\left[\mathrm{Pt}_{2} \mathrm{~L}_{4}\right][\mathrm{OTf}]_{4}(\mathbf{1 b})$ was demonstrated by electrospray spectrometry, in which the $\left[\mathrm{Pt}_{2} \mathrm{~L}_{4}\right]^{4+}$ fragment with varying numbers of triflate counterions was observed. The ${ }^{1} \mathrm{H}$ NMR spectrum of $1 \mathrm{~b}$ was recorded in $\mathrm{CD}_{3} \mathrm{CN}$ due to solubility limitations. The spectrum shows that the coordinated ligands in $\mathbf{1 b}$ display a symmetric pattern close to the free ligand $\mathrm{L}$. A downfield shift relative to free ligand was observed, particularly for the $\mathrm{H}_{\mathrm{a}}$ and $\mathrm{H}_{\mathrm{e}}$ protons (Figure S2). Full characterization of $1 \mathrm{~b}$ is given in the supporting information.

We then investigated the host-guest properties of the metallacage $\mathbf{1 b}$ towards the metal complex guest $[n$ $\left.\mathrm{Bu}_{4} \mathrm{~N}\right]\left[\mathrm{Au}(\mathrm{bdt})_{2}\right]$ under similar conditions to those used for the palladium cage $\left[\mathrm{Pd}_{2} \mathrm{~L}_{4}\right][\mathrm{OTf}]_{4}(\mathbf{1 a})$. It is worth mentioning that examples where a square metal complex is encapsulated within a metallacage, especially in the case of a platinum capsule, are limited 27,28 and more scarce when the complex displays thioligands because they are also able to bind the metal centre. ${ }^{41}$ When the host molecule $\left[\mathrm{Pt}_{2} \mathrm{~L}_{4}\right][\mathrm{OTf}]_{4}(\mathbf{1 b})$ was treated by one equivalent of the guest complex $\left[n-\mathrm{Bu}_{4} \mathrm{~N}\right]\left[\mathrm{Au}(\mathrm{bdt})_{2}\right]$ in a mixture of $\mathrm{CD}_{3} \mathrm{CN} / \mathrm{DMSO}-d_{6}$ (4:1), pronounced chemical shift changes were observed for the anionic complex and the cage as well, suggesting the encapsulation of the guest. For instance the signals attributed to hydrogens $\mathrm{H}_{\mathrm{e}}$ and $\mathrm{H}_{\mathrm{a}}$ for $\mathbf{1 b}$ moved from $\delta 9.34 \mathrm{ppm}$ and $\delta 9.06 \mathrm{ppm}$ to $\delta 9.92 \mathrm{ppm}$ and $\delta 9.39 \mathrm{ppm}$ while the NMR resonances of the aromatic protons $\mathrm{H}_{2}$ and $\mathrm{H}_{3}$ for the guest changed from $\delta 7.09 \mathrm{ppm}$ and $\delta 6.78 \mathrm{ppm}$ to $\delta 7.21 \mathrm{ppm}$ and $\delta 6.31 \mathrm{ppm}$ (Figure 2c, Figure S3). Addition of another equivalent of guest molecule led to two novel signals at $\delta 7.09$ ppm and $\delta 6.78 \mathrm{ppm}$, which correspond to the signals of free $\mathrm{Au}(\mathrm{III})$ guest (Figure 2d). No changes in the ${ }^{1} \mathrm{H}$ NMR spectrum occurred in the presence of an excess of guest molecules. Moreover upon leaving the solution to stand over time no evolution occurred, suggesting that this host-guest system is kinetically and thermodynamically stable. These results contradict completely those obtained for the analogous and more labile $\mathrm{Pd}_{2} \mathrm{~L}_{4}$ metallacage 1a, highlighting the robust nature of our platinum cage $1 \mathrm{~b}$.

We then attempted to isolate the host-guest assembly. Thus, treatment of $\mathbf{1 b}$ with excess of $[n$ $\left.\mathrm{Bu}_{4} \mathrm{~N}\right]\left[\mathrm{Au}(\mathrm{bdt})_{2}\right]$ in $\mathrm{CH}_{3} \mathrm{CN}$, afforded a green precipitate which was isolated and characterized by NMR spectroscopy in DMSO $\left({ }^{1} \mathrm{H}-,{ }^{13} \mathrm{C}-, 1 \mathrm{D}\right.$ and 2D-NMR experiments) as $\left[\mathrm{Au}(\mathrm{bdt})_{2} \subset \mathrm{Pt}_{2} \mathrm{~L}_{4}\right]\left[\mathrm{Au}(\mathrm{bdt})_{2}\right]_{3}(\mathbf{2})$. Moreover, the existence of assembly 2 in solution was confirmed by electrospray mass spectrometry. The +3 and +2 charge state of the $\left\{\left[\mathrm{Au}(\mathrm{bdt})_{2} \subset \mathrm{Pt}_{2} \mathrm{~L}_{4}\right]\right\}$ and $\left\{\left[\mathrm{Au}(\mathrm{bdt})_{2} \subset \mathrm{Pt}_{2} \mathrm{~L}_{4}\right]\left[\mathrm{Au}(\mathrm{bdt})_{2}\right]\right\}$ fragments appear respectively at $\mathrm{m} / \mathrm{z}=701.76338$ and at $\mathrm{m} / \mathrm{z}=$ 1291.10670 and were verified by comparison of the observed and theoretical isotopic patterns (Figure

Figure 2. ${ }^{1} \mathrm{H}$ NMR host-guest studies with metallacage $\mathbf{1 b}$ in the presence of $\left[n-\mathrm{Bu}_{4} \mathrm{~N}\right]\left[\mathrm{Au}(\mathrm{bdt})_{2}\right]$ in $\mathrm{CD}_{3} \mathrm{GN} / \mathrm{DMSO}-d_{6}(4: 1)$ a) free $\left[n-\mathrm{Bu} 4_{4} \mathrm{~N}\right]\left[\mathrm{Au}(\mathrm{bdt})_{2}\right]$ guest b) the cage complex $\mathbf{1 b}$ c) 1 eq. of $[n$ $\left.\left.\mathrm{Bu}_{4} \mathrm{~N}\right]\left[\mathrm{Au}(\mathrm{bdt})_{2}\right] \mathrm{d}\right)$ excess of $\left[n-\mathrm{Bu}_{4} \mathrm{~N}\right]\left[\mathrm{Au}(\mathrm{bdt})_{2}\right]$. (Hint $=\mathrm{H}$ interior Hext $=\mathrm{H}$ exterior $)$.
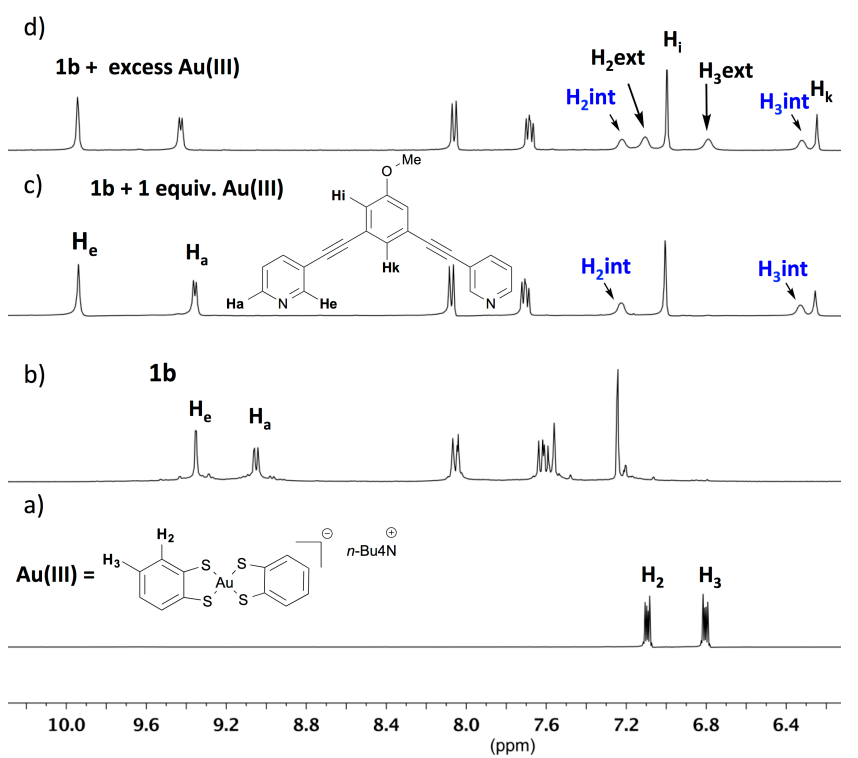

The ${ }^{1} \mathrm{H}-\mathrm{NMR}$ spectrum displayed two series of resonances for the $\mathrm{Au}(\mathrm{III})$ complex : two doublets of doublets at $\delta 7.08 \mathrm{ppm}$ and $\delta 6.80 \mathrm{ppm}$ corresponding to $\mathrm{H}_{2}$ and $\mathrm{H}_{3}$ protons of free $\mathrm{Au}(\mathrm{bdt})_{2}$ molecules and two other doublets of doublets at $\delta 7.13 \mathrm{ppm}$ and $\delta 6.34 \mathrm{ppm}$ corresponding to $\mathrm{H}_{2}$ and $\mathrm{H}_{3}$ protons of encapsulated $\mathrm{Au}(\mathrm{III})$ complex, respectively in $3 / 1$ ratio. 2D NOESY experiment showed correlation between $\mathrm{H}_{\mathrm{e}}$ proton of $\mathrm{Pt}_{2} \mathrm{~L}_{4}$ host and $\mathrm{H}_{2}$ proton from $\left[\mathrm{Au}(\mathrm{bdt})_{2}\right]$ - guest, proving the encapsulation of the latter. In addition $\mathrm{H}_{\mathrm{k}}$ protons which point to the interior of the cage moved up-field (from $\delta 7.56 \mathrm{ppm}$ to $\delta 6.22 \mathrm{ppm})$ and are perpendicular to the $\mathrm{Au}(\mathrm{III})$ guest since no NOE correlation was observed between $\mathrm{H}_{\mathrm{k}}$ and $\mathrm{H}_{2}$ or $\mathrm{H}_{3}$. Finally, NOESY spectra showed exchange between the encapsulated $\mathrm{Au}(\mathrm{III})$ complex and the free $\left[\mathrm{Au}(\mathrm{bdt})_{2}\right]$-molecule is occurring (Figure S5). Interestingly the ${ }^{195} \mathrm{Pt}-\mathrm{H}$ couplings are initially visible for complex $\mathbf{1 b}$ but disappear just after guest addition confirming this dynamic exchange. As shown in Figure S4 in the supporting information, both free cage and complexed-cage protons were seen in the spectrum, during sequential 
guest additions, indicating a slow exchange of the host-guest complex. ${ }^{42}$

Figure 3. Experimental and theoretical isotope distribution of a) $\left\{\left[\mathrm{Au}(\mathrm{bdt})_{2} \subset \mathrm{Pt}_{2} \mathbf{L}_{4}\right]\right\}$ and b) $\left\{\left[\mathrm{Au}(\mathrm{bdt})_{2} \subset \mathrm{Pt}_{2} \mathbf{L}_{4}\right]\left[\mathrm{Au}(\mathrm{bdt})_{2}\right]\right\}$
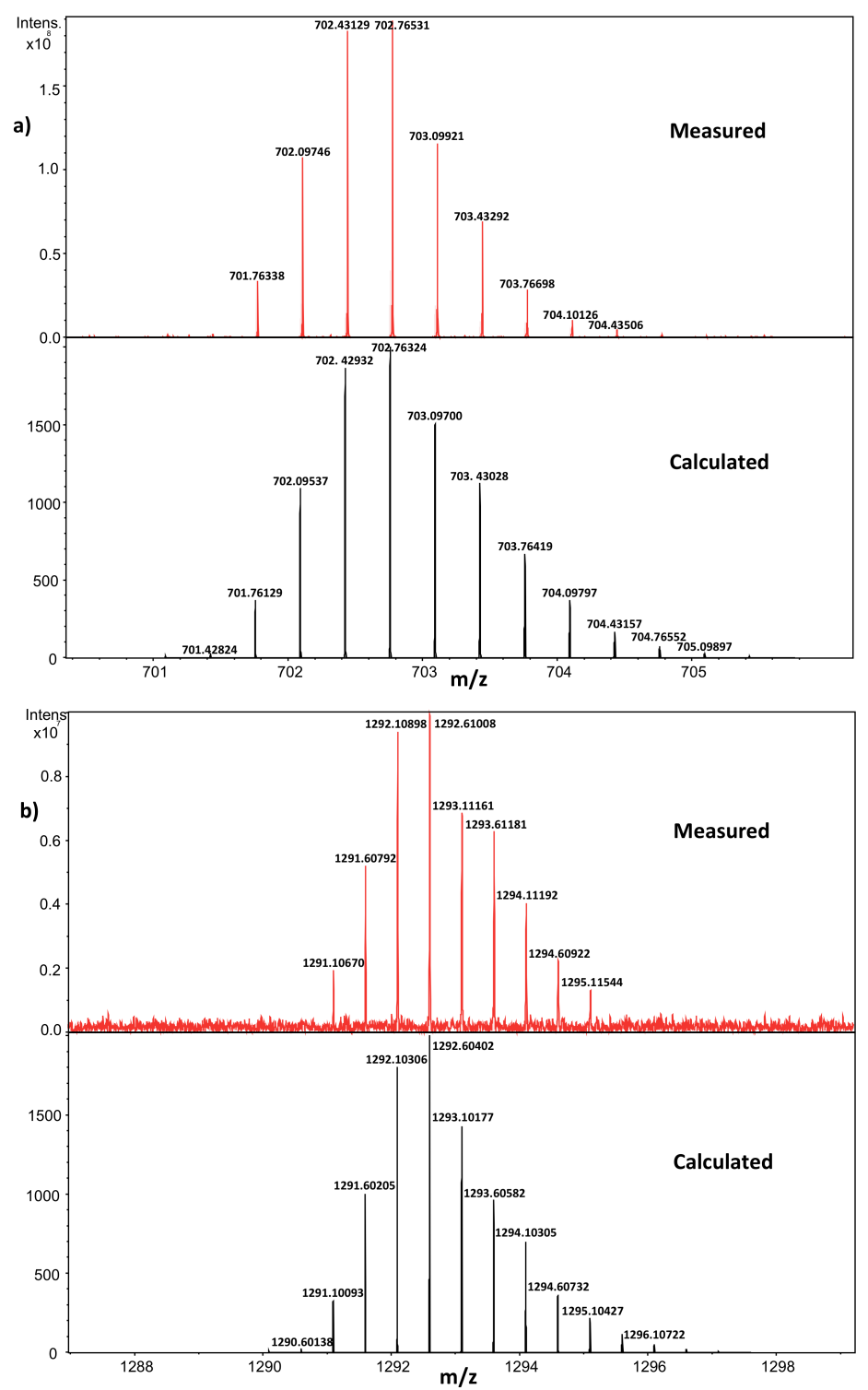

$\left.\mathrm{Bu}_{4} \mathrm{~N}\right]\left[\mathrm{Au}(\mathrm{bdt})_{2}\right]$ provided crystals adequate for $\mathrm{X}$ ray structural determination. The solid state structure was identified stoichiometrically as $\left[\mathrm{Au}(\mathrm{bdt})_{2} \subset \mathrm{Pt}_{2} \mathbf{L}_{4}\right]\left[\left(\mathrm{Au}(\mathrm{bdt})_{2}\right)_{2.5}(\mathrm{OTf})_{0.5}\right](\mathbf{3})$ i.e. a $1: 1$ ratio of $\left[\mathrm{Au}(\mathrm{bdt})_{2} \subset \mathrm{Pt}_{2} \mathbf{L}_{4}\right]\left[\mathrm{Au}(\mathrm{bdt})_{2}\right]_{3}$ and $\left[\left(\mathrm{Au}(\mathrm{bdt})_{2} \subset \mathrm{Pt}_{2} \mathbf{L}_{4}\right]\left[\left(\mathrm{Au}(\mathrm{bdt})_{2}\right)_{2}(\mathrm{OTf})\right]\right.$. In all cages the $\mathrm{X}$-ray structure showed the presence of one encapsulated molecule of the anionic $\left[\mathrm{Au}(\mathrm{bdt})_{2}\right]^{-}$complex inside the cavity of $\mathrm{Pt}_{2} \mathrm{~L}_{4}$ cage and the presence of free $\left[\mathrm{Au}(\mathrm{bdt})_{2}\right]$ - in accord with the ${ }^{1} \mathrm{H}-\mathrm{NMR}$ solution studies (Figure 4). The $\mathrm{Pt}-\mathrm{N}$ bond lengths lie in the range of 2.01-2.03 $\AA$. The Pt---Pt distance is $11.880(2) \AA$ and the average distance between two facing phenyl rings is around $10.7 \AA$ so that the cavity size is comparable to that observed for cage $\mathbf{1 a} \cdot{ }^{37}$ The anionic $\left[\mathrm{Au}(\mathrm{bdt})_{2}\right]$ guest is located inside the cavity and adopts a perpendicular orientation relative to planes containing the square platinum centers. The three metal centers Pt---Au---Pt are not perfectly aligned, and the $\mathrm{Pt--} \mathrm{Au}$ distances are 5.962(1) and 5.999(1) $\AA$, precluding any direct metal-metal interaction. However, the guest interacts with the frame of the cage via hydrogen bonding interactions between each sulfur atom of the $\left[\mathrm{Au}(\mathrm{bdt})_{2}\right]^{-}$and two ortho aromatic protons from two different coordinated pyridines. Indeed, the $\mathrm{C}---\mathrm{S}$ and $\mathrm{H}---\mathrm{S}$ distances lie respectively in the range of 3.65-3.89 $\AA$ and 2.76-2.99 $\AA$, with C-H---S bond angles of ca. 139 to $171^{\circ}$. These values are comparable to those reported for complexes displaying CH---S bonding interactions. ${ }^{43}$ On the other hand the structure reveals the presence of other anionic molecules $\left[\mathrm{Au}(\mathrm{bdt})_{2}\right]^{-}$located outside the assembly, but stacking perfectly over the platinum centres of the cage (Figure 3). The Au---Pt distances are 4.626 (1) and 4.698 (1) $\AA$, larger than the sum of van der Waals radii $(3.73 \AA)$ precluding any metal - metal interaction. ${ }^{44}$

Figure 4. a) X-ray crystal structure of $\left[\mathrm{Au}(\mathrm{bdt})_{2}\right] \subset\left[\mathrm{Pt}_{2} \mathrm{~L}_{4}\right]\left[\left(\mathrm{Au}(\mathrm{bdt})_{2}\right)\right]^{2+}$. For clarity purposes only the encapsulated $\mathrm{Au}(\mathrm{III})$ guest and one $\mathrm{Au}(\mathrm{bdt})_{2}$ outside the cavity perched over the $\mathrm{Pt}(\mathrm{II})$ centre are shown. b) 1D chain made of host-guest assemblies interacting with the outside $\mathrm{Au}(\mathrm{bdt})_{2}{ }^{-1}$ species. All hydrogen atoms are omitted, thermal displacement ellipsoids are shown at $30 \%$ probability. 
a)

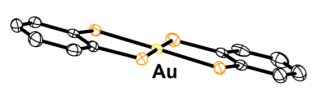

b)

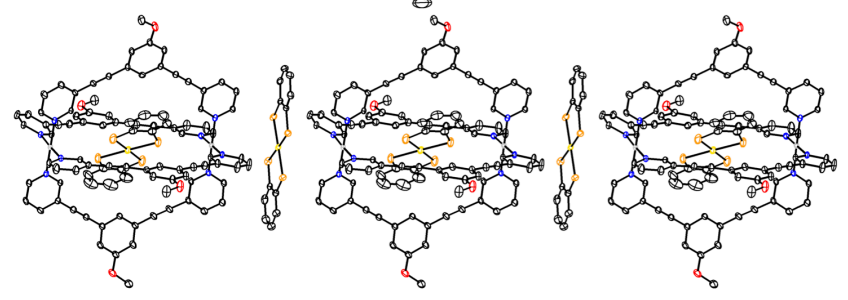

To shed light on the nature of the host-guest interactions in the supramolecular assembly, properties of the host-guest complex were calculated by density functional theory (DFT), using both the B3LYPD345-47 and M0648 methods, and several basis sets for comparison. ${ }^{49-53}$ Additional details are provided in the Supplemental Information.

The gas-phase host-guest complexation energies were calculated to be quite similar among the different basis sets and DFT methods, suggesting that these methods are adequate for estimating the energetics. The interior gold guest is predicted to be more strongly bound than the exterior guest, by $12-18$ $\mathrm{kcal} / \mathrm{mol}$ in the absence of dispersion and by 42 $47 \mathrm{kcal} / \mathrm{mol}$ when dispersion is included. This makes sense, given that the interior guest has more near-atom interactions available and also the possibility of $\pi$-stacking interactions between the central methoxyphenyl ring of each arm and the phenyl rings of the guest. Furthermore, the overall binding energy of the two guests with the host is greater than the sum of the individual binding energies, indicating that each guest activates the host towards accepting a second guest. The donor-acceptor interaction energies, including charge-transfer contributions, were estimated by NBO analysis. For both the interior and exterior guests, the dominant contribution arises from the guest acting as a donor to the organic component of the host cage. The $\mathrm{Pt}$ atoms are too distant from the guest molecules for any metal-metal host-guest interaction to account for more than about a quarter of the total binding energy. Looking specifically for Pt-Au interactions, we find that in the case of the exterior guest, most of the energy contribution involving the neighbouring $\mathrm{Pt}$ atom is ascribed to direct Pt-Au interaction, whereas for the interior guest the $\mathrm{Pt}$ atoms interact roughly equally with the $\mathrm{Au}$ atom and with the associated $\mathrm{S}$ atoms. In either case, however, Pt-Au bonding appears to be a small contribution to the stabilization of these guests. Instead, most of the donor-acceptor stabilization is provided by the nearest-neighbour interactions, especially the electropositive hydrogen atoms on the host aryl groups as the acceptors and the guest sulfur atoms and aryl carbons as donors. This is consistent in part with the NBO orbital analysis, which is further discussed in the SI. Unfortunately, a full-scale energy decomposition analysis is prohibitive for a system of this size. However, the present DFT calculations strongly indicate that both guest molecules are stabilized by a combination of dispersion, donor-acceptor interaction, and electrostatics. The interior guest appears to be stabilized largely by the dispersion interaction, whereas electrostatic interactions may play a larger role in stabilizing the exterior guest. Overall, the interior guest is predicted to be more strongly bound to the cage by roughly $40-50 \mathrm{kcal} / \mathrm{mol}$.

\section{- CONCLUDING REMARKS}

In this work we have investigated the encapsulation of square planar gold complex $\left[n-\mathrm{Bu}_{4} \mathrm{~N}\right]\left[\mathrm{Au}(\mathrm{bdt})_{2}\right]$ containing thioligands using metallacages of type $\mathrm{M}_{2} \mathrm{~L}_{4} \mathrm{M}=\operatorname{Pd}(\mathbf{1} \mathbf{a}), \mathrm{M}=\operatorname{Pt}(\mathbf{1} \mathbf{b})$. The latter was prepared using a novel synthetic procedure. While the $\mathrm{Pd}_{2} \mathrm{~L}_{4}$ cage decomposed in the presence of the guest molecule $\left[\mathrm{Au}(\mathrm{bdt})_{2}\right]^{-}$, in stark contrast the platinum cage successfully accommodated an anionic square planar gold(III) complex as demonstrated by NMR techniques (2D NOESY). This result constitutes a rare example in the literature. Furthermore, single crystal X-ray diffraction studies confirm the presence of the gold guest inside the cavity stabilised through hydrogen-bonding with the ligands of the cage $\mathrm{Pt}_{2} \mathrm{~L}_{4}$. The $\mathrm{X}$-ray structure also revealed the presence of a weak interaction between the platinum centre of the assembly and another anionic gold complex located outside the cavity. DFT calculations have been advanced to rationalize the nature of host-guest interactions in this rare and unique assembly

\section{EXPERIMENTAL SECTION}

\section{General synthetic methods}

All solvents used were reagent grade or better. Commercially available reagents were used as received. The ligand $\mathbf{L}$, the solvated platinum building block $\left[\mathrm{Pt}(\mathrm{EtCN})_{4}\right][\mathrm{OTf}]_{2}$, and the goldbis(dithiolene) complex were prepared according to published methods. ${ }^{40,54,55}$ All experimental manipulations were carried out under argon using Schlenk techniques. IR spectra were recorded on a Bruker 
Tensor 27 (Bruker Corp., Rheinstetten, Germany) equipped with a Harrick ATR. Elemental analyses were performed at the Microanalytical Laboratory of the Sorbonne-université. Positive ESI mass spectra were obtained using a triple quadruple mass spectrometer (Quattro II Micromass, Waters, UK). Automatic data acquisition was processed using the software Masslynx V4.0. NMR experiments were carried out on a Bruker Avance II $300 \mathrm{MHz}$, or Bruker Neo $500 \mathrm{MHz}$ spectrometers operating at $300 \mathrm{~K}$ with chemical shifts referenced to residual solvent peaks. Chemical shifts are reported as parts per million (ppm) and coupling constants $(J)$ in hertz $(\mathrm{Hz})$. Standard abbreviations indicating multiplicity were used as follows: $\mathrm{m}=$ multiplet; $\mathrm{t}=$ triplet; $\mathrm{d}=$ doublet; $\mathrm{s}=$ singlet and $\mathrm{b}=$ broad.

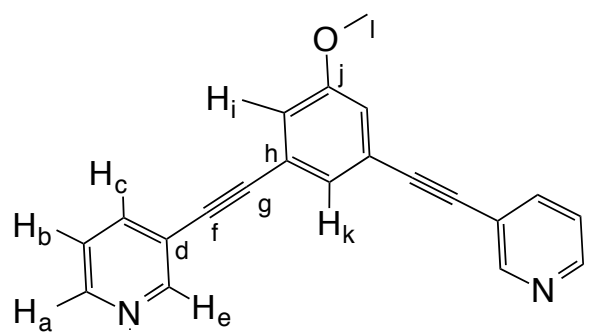

\section{Synthesis of $\left[\mathrm{PtL}_{4}\right][\mathrm{OTf}]_{4}(\mathbf{l b})$}

To an oven dried Schlenk flask equipped with a magnetic stirrer was added $\left.\left[\mathrm{Pt}(\mathrm{EtCN})_{4}\right]_{[\mathrm{OTf}}\right]_{4}(126$ $\mathrm{mg}, \quad 0.176$ mmol, 1 equiv.), 5-Methoxy-1,3bis(pyridin-3-ylethynyl)benzene (L) (140 mg, 0,451 mmol, 2 equiv.) which were solubilized in argondegassed MeCN (30 ml) freshly distilled over $\mathrm{CaH}_{2}$. The solution was heated to reflux and maintained under argon with stirring for four days at $80^{\circ} \mathrm{C}$. The solution was then allowed to cool at room temperature and concentrated under vacuum to $3 \mathrm{ml}$. The mixture was precipitated by slow addition of freshly distilled and degassed diethylether $(20 \mathrm{ml})$. The white solid was filtered using a filtrating cannula, washed three times with diethylether $(10 \mathrm{ml})$ and recrystallized from a mixture of $\mathrm{CH}_{2} \mathrm{Cl}_{2}$, $\mathrm{DMSO} / \mathrm{Et}_{2} \mathrm{O}$. Dried under vacuum to afford the desired product as air-stable white solid. $170 \mathrm{mg}$ (86 $\%$ ).

${ }^{1} \mathrm{H}$ NMR $\left(300 \mathrm{MHz}, \mathrm{CD}_{3} \mathrm{CN}, 298 \mathrm{~K}\right): \delta 9.34(\mathrm{~s}, 8 \mathrm{H}$, $\left.\mathrm{H}_{\mathrm{e}}\right) ; 9.06\left(\mathrm{dd}, 8 \mathrm{H}, \mathrm{J}=6.0,0.5 \mathrm{~Hz}, \mathrm{H}_{\mathrm{a}}\right) ; 8.05(\mathrm{dt}, 8 \mathrm{H}$, $\mathrm{J}=9.0,0.5 \mathrm{~Hz}, \mathrm{H}_{\mathrm{c}}$ ); 7.61 (ddd, 8H, $\mathrm{J}=9.0,6.0$, $\left.0.5 \mathrm{~Hz}, \mathrm{H}_{\mathrm{b}}\right) ; 7.56\left(\mathrm{t}, 4 \mathrm{H}, \mathrm{J}=1.3 \mathrm{~Hz}, \mathrm{H}_{\mathrm{k}}\right) ; 7.24(\mathrm{~d}, 8 \mathrm{H}$, $\left.\mathrm{J}=1.3 \mathrm{~Hz}, \mathrm{H}_{\mathrm{i}}\right), 3.82(\mathrm{~s}, 12 \mathrm{H}, \mathrm{OMe})$. IR $(\mathrm{KBr}):(\mathrm{v}$, $\left.\mathrm{cm}^{-1}\right) \quad v(\mathrm{C} \equiv \mathrm{C})=2219, \quad v(\mathrm{C}-\mathrm{F})=1256, \quad v(\mathrm{~S}=\mathrm{O})$ $=1231, \quad v(\mathrm{~S}-\mathrm{O})=1029 . \mathrm{ES}-\mathrm{MS} \quad(\mathrm{m} / \mathrm{z}):\left[\mathrm{Pt}_{2} \mathrm{~L}_{4}\right]^{4+}$ : 407.59; found: 407.84, $\left[\mathrm{Pt}_{2} \mathrm{~L}_{4}\left(\mathrm{CF}_{3} \mathrm{SO}_{3}\right)\right]^{3+}$ : 593.10; found: 593.84, $\left[\mathrm{Pt}_{2} \mathrm{~L}_{4}\left(\mathrm{CF}_{3} \mathrm{SO}_{3}\right)\right]^{2+}$ : 964.13; found: 964.63; Anal. calcd for $\left[\mathrm{Pt}_{2} \mathrm{~L}_{4}\right][\mathrm{OTf}]_{4}$.DMSO. $\mathrm{CH}_{2} \mathrm{Cl}_{2}: \mathrm{C}$ 45.72, H 2.70, N 4.69; Found: C 45.90, H 1.93, N 4.71.

\section{Synthesis of $\left[\left(\mathbf{A u}(\mathbf{b d t})_{2} \subset \mathbf{P t}_{\mathbf{2}} \mathbf{L}_{\mathbf{4}}\right]\left[\mathbf{A u}(\mathrm{bdt})_{2}\right]_{\mathbf{3}}(\mathbf{2})\right.$}

$\left[n-\mathrm{Bu}_{4} \mathrm{~N}\right]\left[\mathrm{Au}(\mathrm{bdt})_{2}\right]$ (40 mg, $\left.0.056 \mathrm{mmol}\right)$ was added to a solution of $\left[\mathrm{PtL}_{4}\right][\mathrm{OTf}]_{4}(31 \mathrm{mg}, 0.014$ $\mathrm{mmol}$ ) in $\mathrm{CH}_{3} \mathrm{CN}(5 \mathrm{~mL})$. The solution was stirred at room temperature for $30 \mathrm{~min}$, during which time a green precipitate formed. The solid was collected by filtration, washed with diethyl ether $(3 \times 5 \mathrm{~mL})$, and dried under vacuum: $42 \mathrm{mg}$ of green solid $(87 \%)$; This metallacage was isolated and characterized as $\left[\mathrm{Au}(\mathrm{bdt})_{2} \subset \mathrm{Pt}_{2}(\mathrm{~L})_{4}\right]\left[\mathrm{Au}(\mathrm{bdt})_{2}\right]_{3} \quad:{ }^{1} \mathrm{H} \quad \mathrm{NMR}$ $\left(500 \mathrm{MHz}, \mathrm{DMSO}-\mathrm{d}_{6}\right): \delta 9.88\left(\mathrm{~s}, 8 \mathrm{H}, \mathrm{H}_{\mathrm{e}}\right), 9.45(\mathrm{~d}, \mathcal{J}$ $\left.=6.0 \mathrm{~Hz}, 8 \mathrm{H}, \mathrm{H}_{\mathrm{a}}\right), 8.23(\mathrm{dt}, \mathcal{F}=7.9 \mathrm{~Hz}, \mathcal{J}=1.4 \mathrm{~Hz}$, $\left.8 \mathrm{H}, \mathrm{H}_{\mathrm{c}}\right), 7.87\left(\mathrm{dd}, \mathcal{F}=7.9 \mathrm{~Hz}, \mathcal{F}=6.0 \mathrm{~Hz}, 8 \mathrm{H}, \mathrm{H}_{\mathrm{b}}\right)$, $7.13\left(\mathrm{dd}, \mathcal{J}=5.9 \mathrm{~Hz}, \mathcal{J}=3.1 \mathrm{~Hz}, 4 \mathrm{H}, \mathrm{H}_{2 \text { int }}\right), 7.08$ $\left(\mathrm{dd}, \mathcal{J}=5.9 \mathrm{~Hz}, \mathcal{F}=3.2 \mathrm{~Hz}, 12 \mathrm{H}, \mathrm{H}_{2 \mathrm{ext}}\right), 7.02(\mathrm{~d}, \mathcal{F}=$ $\left.1.2 \mathrm{~Hz}, 8 \mathrm{H}, \mathrm{H}_{\mathrm{i}}\right), 6.80(\mathrm{dd}, \mathcal{f}=5.9 \mathrm{~Hz}, \mathcal{f}=3.2 \mathrm{~Hz}$, $\left.12 \mathrm{H}, \mathrm{H}_{3 \mathrm{ext}}\right), 6.34(\mathrm{dd}, \mathcal{J}=5.9 \mathrm{~Hz}, \mathcal{J}=3.1 \mathrm{~Hz}, 4 \mathrm{H}$, $\left.\mathrm{H}_{3 \text { int }}\right), 6.22\left(\mathrm{t}, \mathcal{J}=1.2 \mathrm{~Hz}, 4 \mathrm{H}, \mathrm{H}_{\mathrm{k}}\right), 3.72(\mathrm{~s}, 12 \mathrm{H}$, OMe).). ${ }^{13} \mathrm{C}-\mathrm{NMR}\left(\mathrm{CDCl}_{3}, 125 \mathrm{MHz}\right): \delta=158.8$ $(\mathrm{Cij}), 154.4\left(\mathrm{C}_{\mathrm{e}}\right), 151.1\left(\mathrm{C}_{\mathrm{a}}\right), 143.3\left(\mathrm{C}_{\mathrm{c}}\right), 141.7\left(\mathrm{C}_{\text {lext }}\right)$, $128.3\left(\mathrm{C}_{2 \text { int }}\right), 128.1\left(\mathrm{C}_{\mathrm{b}}\right), 128.0\left(\mathrm{C}_{2 \text { ext }}\right), 126.9\left(\mathrm{C}_{\mathrm{k}}\right)$, $123.8\left(\mathrm{C}_{3 \text { int }}\right), 123.3\left(\mathrm{C}_{3 \text { ext }}\right.$ and $\left.\mathrm{C}_{\mathrm{d}}\right), 122.4\left(\mathrm{C}_{\mathrm{h}}\right), 118.3$ $\left(\mathrm{C}_{\mathrm{i}}\right), 94.4\left(\mathrm{C}_{\mathrm{g}}\right), 83.9\left(\mathrm{C}_{\mathrm{f}}\right), 55.7\left(\mathrm{G}_{\mathrm{l}}\right)$. ES-HRMS $(\mathrm{m} / \mathrm{z})$ : $\left[\mathrm{L}_{4} \mathrm{Pt}_{2}\left(\mathrm{Au}(\mathrm{bdt})_{2}\right)\right]^{3+}:$ 701.76129; found : 701.76338, $\left[\mathrm{L}_{4} \mathrm{Pt}_{2}\left(\mathrm{Au}(\mathrm{bdt})_{2}\right)_{2}\right]^{2+}: 1291.10093 ; \quad$ found : 1291.10670. All attempts to obtain crystals of this compound were unsuccessful.

\section{$X$-ray crystal structure of $\left[\mathbf{A u}(\mathbf{b d t})_{2} \subset \mathbf{P t}_{2} \mathbf{L}_{4}\right]\left[\mathbf{A u}(\mathbf{b d t})_{2}\right]_{2.5}(\mathbf{O T f})_{0.5}(3)$}

Diffusion of diethyl ether into acetonitrile/DMSO (4:1) solution of $\mathbf{1 b}$ in the presence of excess [ $n$ $\left.\mathrm{Bu}_{4} \mathrm{~N}\right]\left[\mathrm{Au}(\mathrm{bdt})_{2}\right]$ provided suitable crystals. A single crystal was selected, mounted and transferred into a cold nitrogen gas stream. Intensity data was collected with a Bruker Kappa-APEX2 system using finefocus sealed tube Mo-Ka radiation. Unit-cell parameters determination, data collection strategy, integration and absorption correction were carried out with the Bruker APEX2 suite of programs. The structure was solved with SHELXT-201456 and refined anisotropically by full-matrix least-squares methods with SHELXL-201456 using the WinGX suite. ${ }^{57}$ Significant electron density remains near gold and platinum atoms despite our repeated attempts at improving absorption correction. The crystal contains severely disordered and partially missing molecules of volatile solvent (diethyl ether, dimethyl sulfoxide and/or acetonitrile). PLATON SQUEEZE $^{58}$ was used for the final refinement cycles to account for the resulting voids. The structure was deposited at the Cambridge Crystallographic Data Centre with number CCDC 1841449 and can be obtained free of charge via www.ccdc.cam.ac.uk.

\section{Grystal data for 3}

Yellow plate, $\mathrm{C}_{134.5} \mathrm{H}_{104} \mathrm{Au}_{3.5} \mathrm{~F}_{1.5} \mathrm{~N}_{8} \mathrm{O}_{7.5} \mathrm{Pt}_{2} \mathrm{~S}_{14.5}$, triclinic P - 1, a $=12.8265(9) \AA, \mathrm{b}=21.1589(15) \AA$, c 
$=27.9767(21) \AA, \alpha=107.374(3)^{\circ}, \beta=94.244(3)^{\circ}, \gamma$ $=98.877(2)^{\circ}, \mathrm{V}=7101.2(9) \AA^{3}, \mathrm{Z}=4, \mathrm{~T}=200(1) \mathrm{K}$, $\lambda=0.71073 \AA, \mu=5.834 \mathrm{~mm}^{-1}$, min / max transmission $=0.24 / 0.90, \theta$ range $=0.77^{\circ}$ to $30.55^{\circ}$, 209447 reflections measured, 43422 independent $\left(\mathbf{R}_{\text {int }}=0.0384\right), 30862$ observed $[\mathrm{I}>2 \sigma(\mathrm{I})]$, completeness $=0.997,1661$ parameters, 334 restraints, final $\mathrm{R}$ indices $\mathrm{R} 1[\mathrm{I}>2 \sigma(\mathrm{I})]=0.0643$ and $\mathrm{wR} 2$ (all data $)=0.1750$, GOF on $\mathrm{F}^{2}=1.054$, largest difference peak $/$ hole $=7.82 /-6.15$ e. $\AA^{-3}$.

\section{ASSOCIATED CONTENT}

\section{Supporting Information}

The Supporting Information is available free of charge on the ACS Publications website. CGDG reference number 1841449 contains crystallographic data for complexes $\mathbf{3}$ presented in this paper. These data can be obtained free of charge from the Cambridge Crystallographic Data Centre via www.ccdc.cam.ac.uk/data_request/cif.

Additional figures and tables (PDF)

\section{- AUTHOR INFORMATION}

\section{Corresponding Author}

*E-mail: hani.amouri@sorbonne-universite.fr. Phone: +33-1-44273083.

*E-mail:Christophe.desmarets@sorbonne-universite.fr.

\section{Author Contributions}

The manuscript was written through contributions of all authors. All authors have given approval to the final version of the manuscript.

\section{Funding Sources}

\section{- ACKNOWLEDGMENT}

Sorbonne Université-Campus Pierre et Marie Curie, CNRS and Ile de France region for financial support of the $500 \mathrm{MHz}$ NMR spectrometer to Chimie Paristech are gratefully acknowledged. Financial support from the National FT-ICR network (FR 3624 GNRS) for conducting the research is gratefully acknowledged 


\section{REFERENCES}

1. Fujita, M.; Umemoto, K.; Yoshizawa, M.; Fujita, N.; Kusukawa, T.; Biradha, K. Molecular paneling via coordination. Chem. Commun. 2001, 509-518.

2. Caulder, D. L.; Raymond, K. N. Supermolecules by design. Acc. Chem. Res. 1999, 32, 975-982.

3. Ward, M. D. Polynuclear coordination cages. Chem Commun. 2009, 4487-4499.

4. Severin, K. Self-assembled organometallic receptors for small ions. Coord. Chem. Rev. 2003, 245, 3-10.

5. Fujita, M.; Tominaga, M.; Hori, A.; Therrien, B. Coordination Assemblies from a $\mathrm{Pd}(\mathrm{II})$-Cornered Square Complex. Acc. Chem. Res. 2005, 38, 369-378.

6. Chakrabarty, R.; Mukherjee, P. S.; Stang, P. J. Supramolecular Coordination: Self-Assembly of Finite Twoand Three-Dimensional Ensembles. Chem. Rev. 2011, 111, 6810-6918.

7. Mirtschin, S.; Slabon-Turski, A.; Scopelliti, R.; Velders, A. H.; Severin, K. A Coordination Cage with an Adaptable Cavity Size. J. Am. Chem. Soc. 2010, 132, 1400414005.

8. Amouri, H.; Desmarets, C.; Moussa, J. Confined Nanospaces in Metallocages: Guest Molecules, Weakly Encapsulated Anions, and Catalyst Sequestration. Chem. Rev. 2012, 112, 2015-2041.

9. Smulders, M. M. J.; Riddell, I. A.; Browne, C.; Nitschke, J. R. Building on architectural principles for threedimensional metallosupramolecular construction. Chem. Soc. Rev. 2013, 42, 1728-1754.

10. Han, M.; Engelhard, D. M.; Clever, G. H. Selfassembled coordination cages based on banana-shaped ligands. Chem. Soc. Rev. 2014, 43, 1848-1860.

11. Li, H.; Yao, Z. J.; Liu, D.; Jin, G. X. Multi-component coordination-driven self-assembly toward heterometallic macrocycles and cages. Coord. Chem. Rev. 2015, 293, 139157.

12. Freye, S.; Michel, R.; Stalke, D.; Pawliczek, M.; Frauendorf, H.; Clever, G. H. Template Control over Dimerization and Guest Selectivity of Interpenetrated Coordination Cages. J. Am. Chem. Soc. 2013, 135, 84768479 .

13. Harris, K.; Fujita, D.; Fujita, M. Giant hollow MnL2n spherical complexes: structure, functionalisation and applications. Chem. Commun. 2013, 49, 6703-6712.

14. Szaloki, G.; Croue, V.; Carre, V.; Aubriet, F.; Aleveque, O.; Levillain, E.; Allain, M.; Arago, J.; Orti, E.; Goeb S.; Salle, M. Controlling the Host-Guest Interaction Mode through a Redox Stimulus. Angew. Chem., Int. Ed. 2017, 56, 16272-16276.

15. Turega, S.; Cullen, W.; Whitehead, M.; Hunter, C. A.; Ward, M. D. Mapping the Internal Recognition Surface of an Octanuclear Coordination Cage Using Guest Libraries. J. Am Chem. Soc. 2014, 136, 8475-8483.

16. Wang, Q.-Q.; Gonell, S.; Leenders, S. H. A. M.; Duerr, M.; Ivanovic-Burmazovic, I.; Reek, J. N. H. Selfassembled nanospheres with multiple endohedral binding sites pre-organize catalysts and substrates for highly efficient reactions. Nat. Chem. 2016, 8, 225-230.

17. Nishioka, Y.; Yamaguchi, T.; Kawano, M.; Fujita, M. Asymmetric [2 + 2] Olefin Cross Photoaddition in a SelfAssembled Host with Remote Chiral Auxiliaries. J. Am. Chem. Soc. 2008, 130, 8160-8161.

18. Therrien, B.; Suss-Fink, G.; Govindaswamy, P.; Renfrew, A. K.; Dyson, P. J. The "Complex-in-a-Complex" cations $\quad[($ acac $)(2) M \quad$ subset of RU6(p$\mathrm{iPrC}(6) \mathrm{H}(4) \mathrm{Me})(6)(\mathrm{tpt})(2)(\mathrm{dhbq})(3)](6+)$ : A Trojan horse for cancer cells. Angew. Chem., Int. Ed. 2008, 47, 3773-3776.

19. Casini, A.; Woods, B.; Wenzel, M. The Promise of Self-Assembled 3D Supramolecular Coordination Complexes for Biomedical Applications. Inorg. Chem. 2017, 56, 1471514729

20. Zheng, Y. R.; Suntharalingam, K.; Johnstone, T. C.; Lippard, S. J. Encapsulation of $\mathrm{Pt}(\mathrm{IV})$ prodrugs within a $\mathrm{Pt}(\mathrm{II})$ cage for drug delivery. Chem. Sci. 2015, 6, 1189-1193. applications. Coord. Chem. Rev. 2014, 275, 19-36.

22. Lewis, J. E. M.; Gavey, E. L.; Cameron, S. A.; Crowley, J. $\quad$ D. Stimuli-responsive Pd2L4 metallosupramolecular cages: towards targeted cisplatin drug delivery. Chem. Sci. 2012, 3, 778-784.

23. Yamashina, M.; Yuki, T.; Sei, Y.; Akita, M.; Yoshizawa, M. Anisotropic Expansion of an M2L4 Coordination Capsule: Host Capability and Frame Rearrangement. Chem. Eur. J. 2015, 21, 4200-4204.

24. Croue, V.; Krykun, S.; Allain, M.; Morille, Y.; Aubriet, F.; Carre, V.; Voitenko, Z.; Goeb, S.; Salle, M. A selfassembled M2L4 cage incorporating electron-rich 9-(1,3dithiol-2-ylidene)fluorene units. New J. Chem. 2017, 41, 32383241.

25. Preston, D.; Barnsley, J. E.; Gordon, K. C.; Crowley, J. D. Controlled Formation of Heteroleptic [Pd2(La)2(Lb)2]4+ Cages. J. Am. Chem. Soc. 2016, 138, 10578-10585.

26. August, D. P.; Nichol, G. S.; Lusby, P. J. Maximizing Coordination Capsule-Guest Polar Interactions in Apolar Solvents Reveals Significant Binding. Angew. Chem., Int. Ed. 2016, 55, 15022-15026.

27. Clever, G. H.; Kawamura, W.; Tashiro, S.; Shiro, M.; Shionoya, M. Stacked Platinum Complexes of the Magnus Salt Type Inside a Coordination Cage. Angew. Chem., Int. Ed. 2012, 51, 2606-2609.

28. Yoshizawa, M.; Ono, K.; Kumazawa, K.; Kato, T.; Fujita, M. Metal-Metal d-d Interaction through the Discrete Stacking of Mononuclear $\mathrm{M}(\mathrm{II})$ Complexes $(\mathrm{M}=\mathrm{Pt}, \mathrm{Pd}$, and $\mathrm{Cu}$ ) within an Organic-Pillared Coordination Cage. J. Am. Chem. Soc. 2005, 127, 10800-10801.

29. Desmarets, C.; Gontard, G.; Cooksy, A. L.; Rager M. N.; Amouri, H. Encapsulation of a Metal Complex within a Self-Assembled Nanocage: Synergy Effects, Molecular Structures, and Density Functional Theory Calculations. Inorg. Chem. 2014, 53, 4287-4294.

30. Johnstone, M. D.; Schwarze, E. K.; Ahrens, J.; Schwarzer, D.; Holstein, J. J.; Dittrich, B.; Pfeffer, F. M.; Clever, G. H. Desymmetrization of an Octahedral Coordination Complex Inside a Self-Assembled Exoskeleton. Chem. Eur. J. 2016, 22, 10791-10795

31. Chand, D. K.; Balaji, G.; Manivannan, R. Athilakshmi, J. A new class of self-assembly multinuclear $\mathrm{Pt}$ (II) coordination cages by a modular approach. Tetrahedron Lett. 2006, 47, 2867-2869.

32. Kaiser, F.; Schmidt, A.; Heydenreuter, W.; Altmann, P. J.; Casini, A.; Sieber, S. A.; Kuhn, F. E. Self-assembled palladium and platinum coordination cages: Photophysical studies and anticancer activity. Eur. J. Inorg. Chem. 2016 , 5189-5196.

33. Amouri, H.; Mimassi, L.; Rager, M. N.; Mann, B. E.; Guyard-Duhayon, C.; Raehm, L. Host-guest interactions: Design strategy and structure of an unusual cobalt cage that encapsulates a tetrafluoroborate anion. Angew. Chem., Int. Ed. 2005, 44, 4543-4546.

34. Amouri, H.; Desmarets, C.; Bettoschi, A.; Rager, M. N.; Boubekeur, K.; Rabu, P.; Drillon, M. Supramolecular cobalt cages and coordination polymers templated by anion guests: self-assembly, structures, and magnetic properties. Chem. Eur. J. 2007, 13, 5401-5407.

35. Desmarets, C.; Poli, F.; Le Goff, X. F.; Mueller, K.; Amouri, H. A unique type of a dicobalt cage templated by a weakly coordinated hexafluorophosphate anion: design, structure and solid-state NMR investigations. Dalton Trans. 2009, 10429-10432.

36. Desmarets, C.; Policar, C.; Chamoreau, L.-M.; Amouri, H. Design, Self-Assembly, and Molecular Structures of 3D Copper(II) Capsules Templated by BF4- Guest Anions. Eur. J. Inorg. Chem. 2009, 4396-4400.

37. Desmarets, C.; Ducarre, T.; Rager, M. N.; Gontard G.; Amouri, H. Self-assembled M2L4 nanocapsules: synthesis, structure and host-guest recognition toward square planar metal complexes. Materials 2014, 7, 287-301. 
38. Osuga, T.; Murase, T.; Ono, K.; Yamauchi, Y.; Fujita, M. [m x n] Metal Ion Arrays Templated by Coordination Cages. J. Am. Chem. Soc. 2010, 132, 15553-15555.

39. Ray, K.; Weyhermueller, T.; Goossens, A.; Craje, M. W. J.; Wieghardt, K. Do S,S'-Coordinated oDithiobenzosemiquinonate(1-) Radicals Exist in Coordination Compounds? The [AullI(1,2-C6H4S2)2]1-/0 Couple. Inorg. Chem. 2003, 42, 4082-4087.

40. Murata, M.; Kaji, S.; Nishimura, H.; Wakamiya, A.; Murata, Y. Efficient Synthesis of One- and Two-Dimensional Multimetallic Gold-Bis(dithiolene) Complexes. Eur. J. Inorg. Chem. 2016, 3228-3232.

41. Moussa, J.; Chamoreau, L. M.; Gullo, M. P.; Degli Esposti, A.; Barbieri, A.; Amouri, H. Induced phosphorescence from $\mathrm{Pt} \rightarrow \mathrm{Ag}$ and $\mathrm{Ag}(\mathrm{I})$ center dot center dot center dot $\mathrm{Ag}(\mathrm{I})$ metallophilic interactions in benzenedithiolatodiimine-Pt-2/Ag2 clusters: a combined experimental and theoretical investigation. Dalton Trans. 2016, 45, 2906-2913.

42. Thordarson, P. Determining association constants from titration experiments in supramolecular chemistry. Chem. Soc. Rev. 2011, 40, 1305-1323.

43. Krepps, M. K.; Parkin, S.; Atwood, D. A. Hydrogen bonding with sulfur. Cryst. Growth Des. 2001, 1, 291-297.

44. Hayoun, R.; Zhong, D. K.; Rheingold, A. L.; Doerrer, L. H. Gold(III) and Platinum(II) Polypyridyl Double Salts and a General Metathesis Route to Metallophilic Interactions. Inorg. Chem. 2006, 45, 6120-6122.

45. Becke, A. D. Density-Functional Thermochemistry .3. The Role of Exact Exchange. J. Chem. Phys. 1993, 98, 56485652.

46. Lee, C. T.; Yang, W. T.; Parr, R. G. Development of the Colle-Salvetti Correlation-Energy Formula into a Functional of the Electron-Density. Phys. Rev. B 1988, 37, 785-789.

47. Schwabe, T.; Grimme, S. Double-hybrid density functionals with long-range dispersion corrections: higher accuracy and extended applicability. Phys. Chem. Chem. Phys. 2007, 9, 3397-3406.

48. Zhao, Y.; Truhlar, D. G. The M06 suite of density functionals for main group thermochemistry, thermochemical kinetics, noncovalent interactions, excited states, and transition elements: two new functionals and systematic testing of four M06-class functionals and 12 other functionals. Theor. Chem. Acc. 2008, 120, 215-241.

49. Binkley, J. S.; Pople, J. A.; Hehre, W. J. SelfConsistent Molecular-Orbital Methods .21. Small Split-Valence Basis-Sets for 1st-Row Elements. J. Am. Chem. Soc. 1980, 102, 939-947.

50. Dunning, T. H. Gaussian-Basis Sets for Use in Correlated Molecular Calculations .1. The Atoms Boron through Neon and Hydrogen. J. Chem. Phys. 1989, 90, 10071023.

51. Stevens, W. J.; Basch, H.; Krauss, M. Compact Effective Potentials and Efficient Shared-Exponent Basis-Sets for the 1st-Row and 2nd-Row Atoms. J. Chem. Phys. 1984, 81, 6026-6033.

52. Stevens, W. J.; Krauss, M.; Basch, H.; Jasien, P. G. Relativistic Compact Effective Potentials and Efficient, Shared-Exponent Basis-Sets for the 3rd-Row, 4th-Row, and 5th-Row Atoms. Can. J. Phys. 1992, 70, 612-630.

53. Hay, P. J.; Wadt, W. R. Abinitio Effective Core Potentials for Molecular Calculations - Potentials for the Transition-Metal Atoms Sc to Hg. J. Chem. Phys. 1985, 82, 270-283.

54. Desmarets, C.; Azcarate, I.; Gontard, G.; Amouri, H. A Rigid Angular Bidentate Ligand for the Design of a New Class of Coordination Polymers Based on Silver(I) Salts Influence of the Anion on Coordination Assemblies. Eur. J. Inorg. Chem. 2011, 4558-4563.

55. Kukushkin, V. Y.; Oskarsson, A.; Elding, L. I. Tetrakis(propanenitrile)platinum(II) trifluoromethanesulfonate as a suitable intermediate in synthetic $\mathrm{Pt}(\mathrm{II})$ chemistry. Inorg. Synth. 1997, 31, 279-284.

56. Sheldrick, G. M. Crystal structure refinement with SHELXL. Acta Cryst. C 2015, 71, 3-8.

57. Farrugia, L. WinGX suite for small-molecule singlecrystal crystallography. J. Appl. Cryst. 1999, 32, 837-838.
58. Spek, A. L. PLATON SQUEEZE: a tool for the calculation of the disordered solvent contribution to the calculated structure factors. Acta Cryst. C 2015, 71, 9-18. 
SYNOPSIS TOC. A novel platinum-based metallacage $\mathrm{Pt}_{2} \mathrm{~L}_{4}$ has been designed and self-assembled. This nanocage displays a cavity for guest encapsulation. Indeed the $\mathrm{Au}(\mathrm{III})$ metal complex $\left[\mathrm{Au}(\mathrm{bdt})_{2}\right]$ - $(\mathrm{bdt}=$ benzene-1,2-dithiolate) was successfully captured inside the cavity of the $\mathrm{Pt}_{2} \mathrm{~L}_{4}$ and in contrast to that observed for the analogous $\mathrm{Pd}_{2} \mathrm{~L}_{4}$ metallacage.

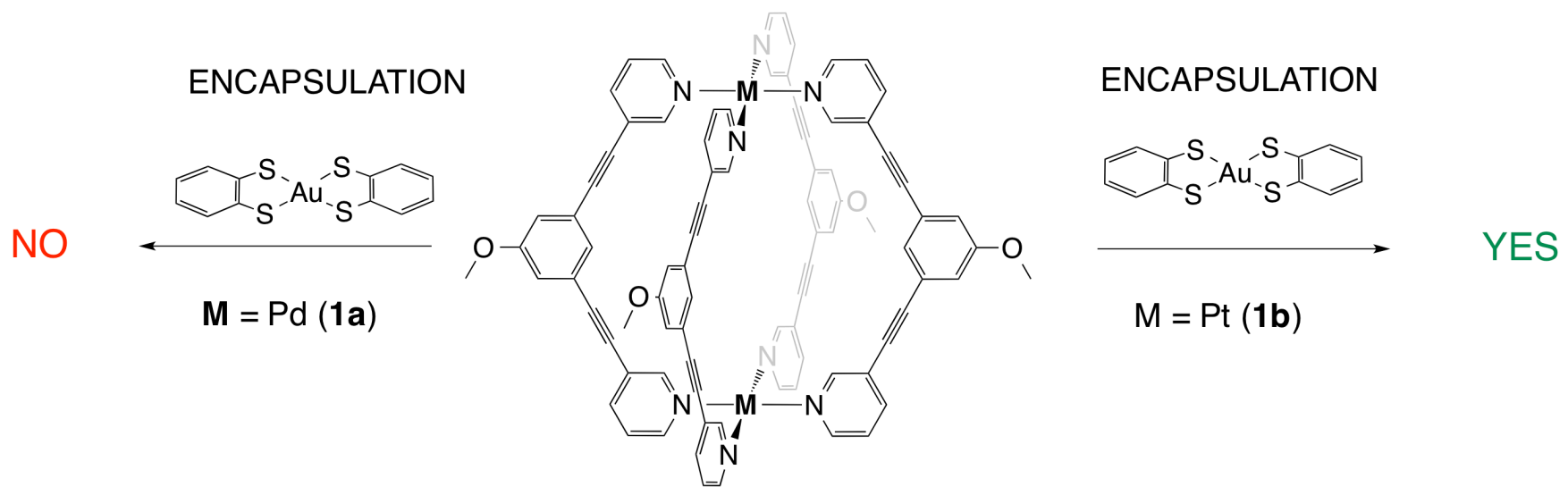

